\title{
TÍMÁR Balázs
}

DOI: 10.15170/DIKE.2020.04.02.11

tudományos segédmunkatárs

MTA TKJTI

\section{„Igény az volna rá” \\ Gondolatok Beck Zoltán „A megszólalás üres helye” című kötetéről}

Beck Zoltán 2020-ban megjelent kötete ígérete szerint a romológiáról és „más dolgok ról” kíván szólni. Alapja a szerző által is bevallottan az évekkel korábbi doktori disszertációja, amellyel számos ponton vitatkozik, s elismeri: nem mindennel ért egyet korábbi önmagával. A monográfia három fő kérdés köré orientálja magát, jelesül a romológia definícióját kívánja adni, ezen túlmenően a roma, cigány irodalom tárgyával kíván foglalkozni, végül a képzőművészet etnikus terének létére kérdez rá.

Nemcsak a romológiáról szóló részek jelentenek újdonságot, hanem mindaz, ami mögötte van, nem érintve a „más dolgokat”.

Mielőtt a romológiára mint fő témára térne a szerző, olyan tudományelméleti alapokat rak le, amelyek nélkül minden további értelmét vesztené. Teszi mindezt mesékkel, melyek közül az első Esopus meséje, $A z$ oroszlánról és a vadászról. ${ }^{3} \mathrm{Ez}$ a látszólag gyermeki felütés karakteresen jelzi az olvasónak: a nézőpont egyszersmind determinálja a tudományos diskurzusban való részvétel lehetőségét és pozícióját - a narratíván keresztül. Márpedig a narratíva birtoklása - ha jobban tetszik: uralása - egyszersmind meghatározza azt is, hogy milyen névvel illetjük azt, amiről beszélünk. Márpedig diskurzus mindaddig nem jöhet létre, amíg nincs neve annak, amiről zajlik. Ez praktikusan az a diszkurzív tér, amibe az egy helyre valókat helyezzük, s ez messze nem oly egyszerű, mint az elsőre tűnik.

Mindennek általában jelentôsége van az elvont, úgynevezett tudományos életben is, amelyre később - elsődlegesen a jogtudomány kapcsán - kívánok visszatérni. Önmagában csak a meséket közlő és magyarázó részek elolvasása is számos pozitív eredménnyel járhat, ugyanakkor adja magát a kérdés, némileg parafrazálva Beck munkájának egy fejezetcímét: érdemes-e erről olvasnia az elképzelt tudósnak?

Az elsődleges válasz az, hogy igen, érdemes. Miként azt az előszóként funkcionáló bevezetés is kimondja, fontos, hogy ezekkel ,foglalkozva legyen", vagyis az a körülmény, hogy ha a mindenkori tudomány csak azzal foglalkozik, amelyet a maga vélt vagy való elitizmussal határos nézőpontjából relevánsnak tart, számos olyan tény, körülmény vagy épp kultúra tűnhet el, amely a mindennapokban nagyon is releváns. Másként megközelítve: azáltal, hogy az úgynevezett

\footnotetext{
1 Adjunktus, PTE BTK Romológia és Nevelésszociológiai Tanszék.

2 BECK Zoltán: A megszólalás üres helye. Budapest 2020, 269 pp.

${ }^{3}$ BECK, A megszólalás üres helye 15.
} 
másodosztállyal foglalkozik a tudomány, egyszersmind biztosítja a létet ezeknek. S ez lehet akár irodalom, vagy bármely reprezentációja akármelyik társadalmi csoportnak, etnikumnak. ${ }^{4}$

Mélyebben belegondolva számos tudományterületen a roma társadalom, vagy bármely akár hazai - nemzetiség valamihez képest szerepel a tudományos kánonban. Akár a mindenkori többségi társadalom jogi, erkölcsi, kulturális álláspontjához viszonyítva, akár annak ellenében meghatározva. Itt merül fel a szükségszerü kérdés: mennyiben lehet állásfoglalást tenni a témában kívülállóként, s mennyiben tud a kívülálló kilépni a valamihez képest rendszeréből? Beck munkájának ez vitathatatlan előnye, hiszen ha nem is mondja meg, hogy mit lehet, vagy épp kell másként tenni, hova helyezzük át a nézőpontot, a fókuszt, megmutatja, hogy mit és mihez képest vizsgálunk. S a másodosztály jelenléte és létjogosultsága akkor válik kézzelfoghatóvá a képzelt tudós számára, amikor feltárul mindaz, ahogyan a többségi társadalom képzelt tagja viszonyul a mindennapokban ehhez.

Mielőtt rátérnék a jog és a történelem vélelmezett képére a roma társadalomról, szükségesnek tartom annak tisztázását, hogy kell-e romológia és szükséges-e ezzel egyetemi (ha úgy tetszik: akadémiai) szinten foglalkozni. A rövid válasz az, hogy igen és erre Beck könyve számos példát és okot hoz. Kezdve azzal, hogy a téma nemzetközi szakirodalmának bemutatásával egyértelmúvé teszi azt a lemaradást, amelyben a hazai romológia lehet. Érdekes adalékként hangzott el Beck előadásán 2020 őszén, hogy az 1989-ig eltelt 150 év alatt Magyarországon 5000 cikk jelent meg a cigányságról, ami évente a három tucatot sem éri el. S ez az általában vett romákat érintő munkák aránya.

A Magyar Tudományos Akadémia Cigány Néprajzi Tanulmányok címmel jelentetett meg periodikát a témában, mintegy kijelölve, hogy a téma a néprajzon belül értelmezendő, mi több, különszám is jelent meg az ezredfordulón A magyarországi nemzetiségek néprajza sorozat tiszteletére. ${ }^{5}$ Szintén az Akadémia berkein belül jelent meg a Ciganisz̨ikeai Tanulmányok címú sorozat, amely megnevezését tekintve még mindig a külső szemléletből fakadó hatalmi megnevezést ${ }^{6}$ követte. Mind a romák, mind a romák kutatásának történetét végül Dupcsik Csaba gyűjtötte össze több, mint egy évtizede.?

Ezeknek megfelelően állítom: érdemes elgondolkodni azon, hogy akár a vizsgált kötet nyomán, akár az általa hivatkozott szerzőkre reflektálva meginduljon egy olyan diskurzus, amelynek a hazai roma társadalom nem tárgya, hanem sokkal inkább alakítója lehet.

Szűkítve a fentieket: érdemes-e jogásznak olvasnia a Megszólalás üres helyét? A válaszhoz indokolt megvizsgálni, hogy a képzelt jog miként viszonyul a romákhoz.

A rendszerváltás óta 309 olyan jogszabály született, amelyben a cigányság valamilyen kontextusban szerepel. Legelőször a Magyar Köztársaságban élő nemzeti és nyelvi kisebbségek országgyúlési képviseletéről szóló törvény ${ }^{8}$ említi, egy sorban a Magyarországon élő

\footnotetext{
${ }^{4}$ BECK, A megszólalás üres helye 9.

${ }^{5}$ https://kisebbsegkutato.tk.hu/uploads/files/olvasoszoba/romaszovegtar/Soha_tobbe_cigany_neprajzi_tanulmany ok_8.pdf (2021.01.13.)

${ }^{6}$ BECK, A megszólalás üres helye 84.

${ }^{7}$ DUPCSIK, A magyarországi cigányság története.

8 A Magyar Köztársaságban élő nemzeti és nyelvi kisebbségek országgyűlési képviseletéről szóló 1990. évi XVII. törvény.
} 
nemzetiségekkel. Leggyakrabban a nemzetiségeket érintő jogalkotás, valamint a költségvetés kapcsán kerül elő, ugyanakkor az ezredfordulót követően már esélyegyenlőségi kérdéssel összefüggésben, míg 2010 után a közfoglalkoztatottsággal kapcsolatban, igaz, alsóbb szinten. Egyetlen kivétel talán 2008-ból a romani és beás nyelvek oktatásáról szóló törvény, amely nemzetközi szerződésből eredő kötelezettséget teljesít. A roma kifejezés ezzel szemben legkorábban törvényi szinten 1991-ben jelenik meg, és azóta közel félezer jogszabály tartalmazza.

A bírói gyakorlatban szereplő cigány részletes vizsgálatára értelemszerüen jelen recenzió nem vállalkozhat, ugyanakkor érdemes kiemelni, hogy közel ezer darab rendes- és alkotmánybírósági döntésben szerepel a kifejezés, míg a roma több, mint ezerben.

Mindezzel csak azt kívántam érzékeltetni, hogy a rendszerváltás óta eltelt bő három évtizedben nem sikerült sem a jogalkotásnak, sem a jogalkalmazásnak dưlőre jutni abban, hogy minek nevezze a homogénnek kezelt roma társadalmat (amely homogenizációba olykor a szerző és a recenzens is hajlamos belefeledkezni). S itt érdemes visszautalni a névadás problematikájához.

A fentiek alapján mint gyakorló jogász azt állítom, hogy a kötet egésze, de akár csak egyes fejezetei is alkalmasak arra, hogy bármely hivatásrend bármely képviselője átértékelje a roma társadalom egyes tagjaihoz füződő viszonyát, mely az elutasítás és gyűlölet végletének akár ellentétes megnyilvánulását is jelentheti.

Az elképzelt történész romaképe már árnyaltabb, amennyiben számos aspektusból vonták már vizsgálat alá a többségi társadalom és a roma közösség kapcsolatát. Leírhatók akár az állam intézkedéseinek vizsgálatával, de akár mikrotörténelmi szinten, vagy épp az egyének szintjén, pl. naplóbejegyzések alapján. Fontos ugyanakkor látni, hogy a történelmi diskurzus esetében a roma sokszor mint tárgy jelenik meg, s nem alanyaként.

Ezek alapján belátható, hogy Beck munkájának ismerete, ha nem is nélkülözhetetlen, mégis releváns bármely történész számára, foglalkozzon akár gazdaság-, akár társadalom-, akár politikatörténettel. Nem azért, mert olyan új adat merül fel, amely nélkül egy-egy kutatás értéktelenebb lenne, hanem azért, mert olyan nézőpontot ad, amelynek tükrében átértékelhetők a kutatási eredmények.

Végezetül utalni kívánok a címben idézett csattanóra, mely tekinthetô talán közismertnek is. A magyarországi roma társadalommal szemben számos előítélet él, s ezek az előítéletek nem kizárólag agresszióban öltenek testet, hanem elhibázott szakpolitikai döntésekben is - függetlenül korszakoktól. A kötet témáját, a feldolgozás módját és a felhasznált forrásait tekintve is alkalmas az előítéletek árnyalására, mi több, számos elôítélet lerombolására. Olvasmányos szövege alkalmassá teszi a laikus olvasó bevonzását, szerkesztése pedig befogadhatóvá teszi azt.

Megjegyzendő ugyanakkor, hogy bizonyos esetekben a lábjegyzetben szereplő információk főszövegben történő kibontása könnyebbé tette volna a megértést, így például a cigánykutatás és szépirodalom kapcsolatánál. ${ }^{10}$ Ugyanez elmondható a hivatkozott nemzetközi szerzők kapcsán is, akikről háttérinformációt nem közöl a monográfia.

A felhasznált szakirodalmak spektruma a tisztán szépirodalmi múvektől az akadémiai értelemben vett szakirodalomig terjednek, és ezek közös nevezőre hozása a szerző nagy erénye.

\footnotetext{
${ }^{9}$ A foglalkoztatás elősegítéséről és a munkanélküliek ellátásáról szóló 1991. évi IV. törvény.

${ }^{10}$ BECK, A megszólalás üres helye 170.
} 
Összességében nemcsak a roma társadalomról kapunk átfogó munkát, hanem a szerzőről is. Beck tudományos pályája ismert, ugyanakkor megítélése szempontjából kiemelt jelentőségű a fenti munka. Szerepe a pécsi romológusképzés megszervezésében ismert, álláspontom szerint e munkával sikerült megtenni a következő lépést. Fontos kiemelni, hogy bár $A$ megszólalás üres helye önmagában is megáll, tudományban betöltött szerepét talán mégis akkor tölti be teljesen, ha ez alapján más tudományterületek is megvizsgálják kutatásaik ilyen irányú átértékelését.

\section{Felhasznált irodalom és források}

A foglalkoztatás elősegítéséről és a munkanélküliek ellátásáról szóló 1991. évi IV. törvény.

A Magyar Köztársaságban élő nemzeti és nyelvi kisebbségek országgyưlési képviseletéről szóló 1990. évi XVII. törvény BECK Zoltán: A megszólalás üres helye. Budapest 2020.

DupCsIK Csaba: A magyarországi cigányság története. Budapest 2009.

https://kisebbsegkutato.tk.hu/uploads/files/olvasoszoba/romaszovegtar/Soha_tobbe_cigany_neprajzi_tanulmanyo k_8.pdf (2021.01. 13.) 